\title{
SCENARIO PLANNING FOR THE ACCELERATION OF REGIONAL BUDGET ABSORPTION: A STUDY ON THE GOVERNMENT OF EAST KOTAWARINGIN
}

\author{
Noor Irwan, Makmur Mochamad, Turachman Hatta* \\ Magister Program of Public Administration, Faculty of Administration, \\ University of Brawijaya, Malang, Indonesia \\ *E-mail: hattahyde1@gmail.com
}

\begin{abstract}
The implication of regional government is still unfulfilling the expectation. One of the indications is regional budget that cannot be absorbed maximally because of the planning weakness and it concentrated in the end of the year. After analyzing the problem of the implication, a scenario is formed in order to gain a scenario planning for the acceleration of regional budget absorption in East Kotawaringin to be realized in the early year to avoid the accumulation by the end of the year. The method used in this research was qualitative descriptive with T-A-I-D method as a tool to form a scenario planning facing every possible scenario. The first step is tracking to look at the main problem happens in the absorption, second is analysis which is to analyze the best and the worst risk toward the effects of politic, economic, social, technology, and environment aspects. The third step is imaging that is an analysis of East Kotawaringin vision, the fourth is deciding which is analyzing the mission to determine the policy in doing certain action or as a program that will be held by the government of East Kotawaringin in the acceleration of regional budget absorption.
\end{abstract}

\section{KEY WORDS}

Scenario planning, acceleration, budget absorption, government.

An ideal budget implication can be marked by a high absorption of the budget, followed by an optimal output and outcome. It also needs to be controlled from the beginning of the planning in order to detect failure of the budget absorption earlier. Report is also important to see the development of budget absorption. To accelerate the absorption of regional budget it needs the rules which orientation is to trust the government in order to use the budget more flexible but still set out the principal of effectiveness, efficiency, and accountability.

The condition of budget absorption in both central and regional government is closely similar. The World Bank mentioned it as slow and back-loaded expenditure. The accumulated absorption here is usually a non-recurrent expenditure such as financial capital and social aid. There also other problem that is related to the low absorption of the budget. The reality shows that a slow absorption of regional budget is also experienced by the Government of East Kotawaringin. The absorption of Estimated Regional Expenditure Budget (APBD) in East Kotawaringin is not optimal yet, it is scientifically proven by budget realization report (Laporan Realisasi Anggaran/LRA) of East Kotawaringin Government for the last three years in the period of 2014-2016.

The expenditure budget realization from 2014 until 2016 averages up to $90.0 \%$ in the fourth trimester during the three years except in 2016, it was under $90.0 \%$. Usually, the condition of budget absorption in the fourth trimester can be said to be an accumulation by the end of the year. Budget absorption which do not reach the target shows that there is an inefficiency of budget allocating and it cause the loss of expenditure benefits which should be experienced by the citizen (Halim, 2014, p.96). This condition is in contrary with 3E principal, benefit principal for people, and the function of APBD.

Regional expenditure is actually a spending done by the government of East Kotawaringin as a fund for the entire program or activity which has whether direct or indirect impact toward the public service in East Kotawaringin. When there is failure in budget absorption target, it means there is inefficiency and ineffectiveness in the budget allocation. The failure in budget absorption of East Kotawaringin is an accumulation the same failure in 
regional functionary organization structure (Struktur Organisasi Perangkat Daerah/SOPD) of East Kotawaringin as an executor of regional autonomy based on each field.

Budget absorption in general only has high acceleration in the end of the year while in the beginning of the year, it usually hard to realize the absorption to be as expected by people. There even a number of SOPD in East Kotawaringin that lack of budget absorbing power in the beginning until the middle of the year. With a strategy planning in the acceleration of budget absorption it expected, first, to improve the program or activity effectiveness so the regional government can finish the program and the activity on time with a good budget realization. Second is to keep the government transparency and accountability in order to achieve development result that can be felt by the citizen. Third is to improve the government credibility so the budget realization is not accumulated in the end of the year and the number of uncompleted program of SOPD can be decreased.

It can be concluded that planning step is the main problem in regional budget absorption that causes the budget cannot be realized as it is planned. It needs to make a budget management system, especially well-planned, structured, and systematic budget absorption. It also needs a scenario planning approach. A planning scenario is closely related with innovation, evaluation, and planning strategy. To apply the planning, a scenario becomes an alternative to start the plan and scenario itself is an image of a future.

Planning scenario method can be used to arrange a medium and long term strategy with uncertain condition. This method can be also be used to identify the future by understanding characteristics and effects that possibly happens. According to Lingred and Bandhold (2003, p.24), scenario planning method can help to sharpen a strategy, arrange a strategy for unexpected thing, also to keep aware in a right path and the right problem. Through he steps in the scenario planning, that uses TAIDA method (Tracking, Analyzing, Imaging, Deciding, Acting), the approach is considered appropriate to help the analysis process of planning strategy in the acceleration of regional budget absorption in East Kotawaringin. It can be seen from the budget absorption that is still slow in the beginning of the year so it needs acceleration in budget absorbing to reach optimum target and of course with a strategy formula through an effective approach that is a scenario planning using T-A-ID method.

\section{LITERATURE REVIEW}

Scenario Planning. In a scenario, a planning scenario is a tool of strategic planning which is an effective tool for medium and long term planning with certain condition. Using scenario will help to sharpen strategy and also to form plan for unexpected things and to keep aware in a right path and right issues. Planning strategy will make a clear image of expected future by looking at any possibilities in the future, such as any unwanted issues. A planning scenario will certainly help in the further development (Lingerd, 2003, p.23).

Meanwhile, the method used in a scenario planning suggested by Lingren and Bandhold (2003, p.38) is using TAIDA (Tracking, Analysing, Imaging, Deciding, Acting) method that is a framework used a scenario planning for public and private organization. Before planning scenario using TAIDA is conducted the first and the most important step is to determine the purpose of scenario planning. Lindgren dan Bandhold (2003) gave four purposes of scenario planning which are 1) awareness of the risk/need for modernity, 2) new thought/paradigm change, 3) business/concept development, and 4) development strategy/organization development. Here are the steps used in TAIDA:

- Tracking. The first step in TAIDA is tracking that is done by investigating and describing changes also the signs of threat and benefit, it also knows its power and weakness. The main purpose is to track and depict trend and changed the entire world which possibly affect the problem, or the question that become the main point of the problem.

- Analyzing. The next step after tracking is analyzing the change and forming a scenario and also analyzing the consequence that probably happens as the result of challenge and opportunity. In this step the logic of scenario is developing. 
- Imaging. After receiving knowledge or vision about things that may happen in the future, the next step is identifying possibilities and making vision of what is desired.

- Deciding. Deciding step is done together by considering information, and identifying choices and strategies. In this step, introduction to the development area and strategy to face the threat in order to reach the vision and purpose is conducted.

- Acting. It is about taking action and following it up. Here showed how a scenario planning can be implemented. This process is a strategy implementation step which has been integrated the scenario, and as a learning step for an organization to keep adapting.

Acceleration of Regional Budget Absorption. Budget absorption acceleration has an important meaning for national purpose which is the improvement and maintaining people's prosperity. It is mentioned in Law Number 17 Year 2003about State Financial that the function of regional budget is an instrument of economic policy, roles to create economic growth and stability and also to create even income distribution in order to reach the purpose of a country. Budget absorption especially goods and service expenditure has a significant effect in supporting economic growth. Therefore every government institution has to manage their spending so it will run well and able to support the success of national development achievement.

Halim (2014, p.97) explained that the assessment of budget implication can be conducted by evaluating the level of budget absorption. Budget is an operational plan of activity stated in financial form of an organization where one part describes cost (spending) estimation and other part describes income estimation to cover up the spending for one certain period, it is usually one year. From the definition of budget, it has to be followed up by realizing the allocated budget based on what is determined in APBD. In this case, the following up is for realization of the activity that has been planned to be held in one year. Thus, the activity realization achievement is a reflection of budget absorption. Therefore, budget absorption is a capability of Ministry/Department/Government to maximize their financial resource utility.

What is meant by absorption here is realization of the budget. Perhaps, absorption generally means an achievement of target estimation achieved in a certain period seen from certain time. People usually mention it as budget dilution. That is why the main focus is public organization or government entity, so budget absorption here can be described as budget dilution or budget realization as what is stated in Budget Realization Report (Laporan Realisasi Anggaran/ LRA) in a certain time (Halim, 2014, p.92).

Budget absorption is a stage of budget cycle started from budget planning, determination, and legalization by representative council (DPR), and then budget absorption, budget monitoring, budget absorption responsibility.

Budget absorption especially goods and service expenditure has a significant effect in supporting economic growth. Therefore every government institution has to manage their spending so it will run well and able to support the success of national development achievement. However, budget absorption does not need to be $100 \%$ but it is expected to be at least more than $80 \%$ of determined budget. The level of budget absorption in SKPD becomes a measurement of its performance in Regional Government.

\section{METHODS OF RESEARCH}

This research was qualitative descriptive. Since this research was to find out the possible scenario to be happened, this research used TAIDA method (Lindgren and Bandhold, 2003).

The data of this research was divided into primary data which were collected from informant and the result of observation, and secondary data in form of supporting documents.

The informant of this research came from Regional Development Planning Department (Badan Perencanaan Pembangunan Daerah/Bappeda) that consisted of The Head of Bappeda (Kepala Bappeda), The Head of Regional Development Planning and Controlling 
Field (Kepala Bidang Perencanaan dan Pengendalian Pembangunan Daerah), The Head of Development Information and Data Collecting Sub Field (Kepala Sub Bidang Pendataan dan Informasi Pembangunan) and also an informant from The Head of Financial and Regional Asset Management Departement (Kepala Badan Pengelola Keuangan dan Aset Daerah).

The document conducted in this research such as Laws, Regional Law (Perda), and various literatures and articles. And then the documents used in this research were RKPD, KUA-PPAS, RKA-SKPD, Raperda APBD, LRA of East Kotawaringin, RPJMD of East Kotawaringin year 2016-2021, and SK Bupati of East Kotawaringin about The Determination of Budget Realization Evaluation and Monitoring of East Kotawaringin Year 2016.

\section{RESULT AND DISCUSSION}

Regional Budget Absorption in East Kotawaringin. The condition of budget absorption from 2014 until 2016 is usually accumulating in the end of the year. The realization that is low in the beginning of the year and tends to accumulate in the end is the main problem of budget application in East Kotawaringin. It can be seen from the several evaluations conducted before 2014. The result is the budget provided in the beginning of the year and should be enjoyed by the citizen in a form of public service through government program or activity cannot be applied because the government tends to spend it in the end of the year. Whereas the expenditure realization can be held earlier, the economic will grow earlier and it will affect to the creation of more vocations, the decreasing of poverty and unemployment people, etc.

The cause of non-optimal budget absorption is because the absorption in the first semester counted from January to July which should be up to $50 \%$ cannot be reached. For the last 3 years from 2014 until 2016, the low level of financial realization in East Kotawaringin keeps continuing in the first semester (January-June). It cannot fulfill the financial realization target for 50\%. Financial realization of East Kotawaringin in June 2016 only reaches $36.27 \%$, it is lower than the realization in 2015 which reached $46.89 \%$ and in 2014 which reached $38.78 \%$. When the second semester (July-December) starts, it will increase and usually accumulate by the end of the year. It happens continuously every year and the budget is used to run the regional development. Most of regional government cannot spend their annual budget (APBD). It can be seen from the budget accumulation that happens every year.

Scenario Planning in the Acceleration of Regional Budget Absorption in East Kotawaringin. To form a right scenario, the first step is identifying trends or issues. Identifying trends will ease the research to describe any possibilities in the future. After knowing the condition of budget absorbing in East Kotawaringin as in previous explanation, it is good to comprehend the trend (the movement direction) of the acceleration in regional budget absorption can be anticipated any possible conditions and situations.

One of the main problems that cause the low realization of expenditure budget absorption of the East Kotawaringin government is on the downstream of the implication cycle of the budget because of the premature planning which is forming and validation of planning and budgeting document that be on the upper course. Planning and budgeting document here are: RKPD, KUA-PPAS, APBD, DPA-SKPD, implementation/technical guidelines, determination of budget management officer. On behalf of that, the entire activities in the upper course should be perfected in $\mathrm{N}-1$ year or a year before the budget runs.

Based on the previous explanation, it can be concluded that budget absorption does not run maximal because the main problem why budget absorption in East Kotawaringin runs slowly is because of the premature planning of the upper course part of budgeting cycle that is the preparation of planning and budgeting document from RKPD and auction document.

The influential aspects that probably happen in budget absorption problem in East Kotawaringin are as follows: 
Table 1 - Influential Aspect of Scenario Planning in the acceleration of Budget Absorption in East Kotawaringin

\begin{tabular}{|l|l|}
\hline \multicolumn{1}{|c|}{ Trend Variable } & \multicolumn{1}{|c|}{ Influential Aspect } \\
\hline Political & Budget Discussing \\
& Regional government's commitment \\
& Policy maker \\
& Regulation determination \\
\hline Economic & Economic growth \\
& Budget planning \\
& Bureaucracy performance \\
& Public service \\
\hline Societal & Human resource \\
\hline Technological & People's prosperity \\
\hline Environment & Innovation of goods and service supply \\
\hline
\end{tabular}

The next step after tracking is analyzing. It aims to analyze any possibilities that may appear in the future, both the wanted or unwanted possibilities. In other word, analyzing is a step where the future consequences are analyzed from the recent change and searching the effect of relationship between trend and tendency to form a scenario.

In this step the pushing factor and the consequences will be identified by understanding how the identified trends interacts each other. In this step the logic of the scenario is also developed. One of the methods used to analyze is cross-impact analysis. In a simple way, the result of cross-impact analysis toward the identified trend in tracking step will be shown in a form of casual-loop diagram as follows:

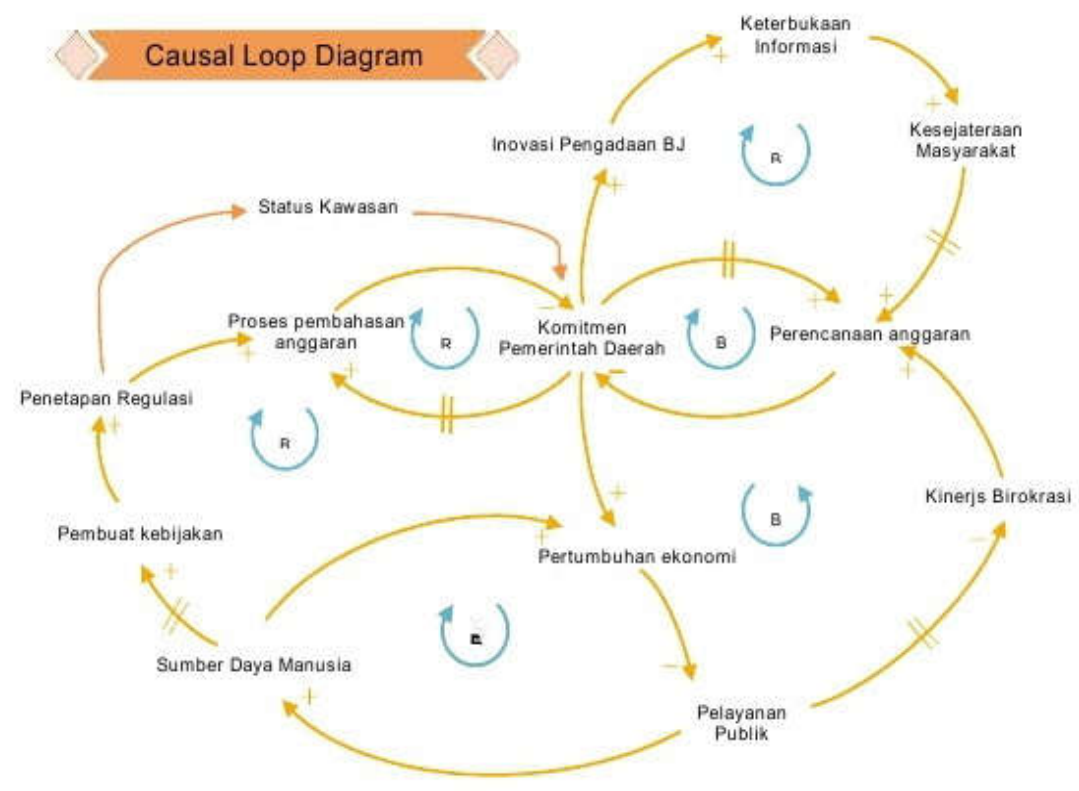

Figure 1 - Cross-Impact Analysis of the Acceleration of Budget Absorption in East Kotawaringin

According to the trend tendency above it can be seen that the most drivers variable is budget planning while the most dependent variable is regional government's commitment. Budget planning and regional government's commitment are the most powerful activator of the entire trends. It causes the acceleration of regional budget absorption cannot run effectively.

Scenario A describes the condition of budget absorption acceleration is affected by a mature planning and supported by regional government's commitment. The budget absorption in East Kotawaringin has always been accumulated in the end of the year and it 
causes the budget absorption is not spread evenly. It is related to budget planning, activity/program, goods and service supply, and documents that need to be prepared earlier before budgeting year is running and also budget discussion conducted by the government and representative council (DPRD) of East Kotawaringin run in the set time. If budget planning and discussion has been prepared and determined it will automatically and directly affects the implication of budget absorption.

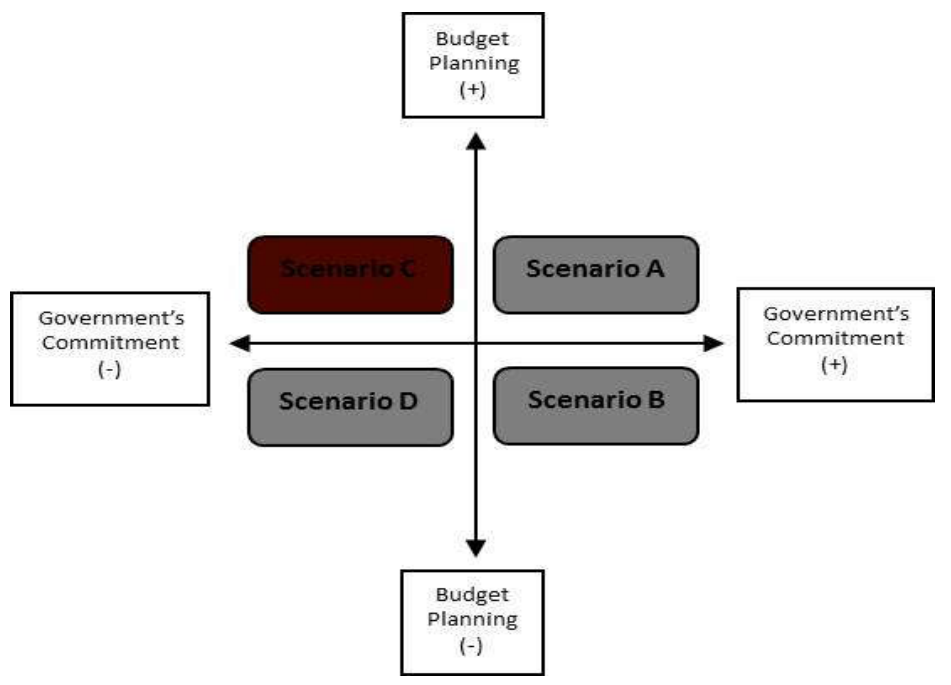

Figure 2 - Four Scenarios for the Acceleration of Budget Absorption in East Kotawaringin

Scenario B describes that the condition of budget absorption acceleration is not good because of the premature planning and supported by regional government's commitment. The problem of this absorption is because of the premature planning of the upper course part of budgeting cycle that is the preparation of planning and budgeting document from RKPD and auction document. The problem that needs to solve is the preparation of planning and budgeting document as a prerequisite of auction. If the document is available, the auction process can be started on time and can be held after agreement between regional government (Bupati) and the Head of DPRD about the planning of regional law (Rancangan Perda) of APBD.

Scenario $C$ shows a mature planning but not supported by regional government's commitment. The activity of budget absorption in in downstream and so much depends on the preparation of planning and budgeting document which is in the upper course. If budget absorption needs to be fixed, the upper course needs to fixed first that is fixing the completion of planning and budgeting documents they are RKPD, KUA-PPAS, APBD, etc. Planning is the most important cycle in budgeting because it decides the budgeting direction, and decides whether a target is well-achieved or not.

Scenario $D$ is the worst planning that describes a premature planning and is not supported by regional government's commitment. In the process of determining an activity/goods and service expenditure planning, SOPD is not mature enough because most of the problems happen caused by the weakness in planning so the budget absorption planning is not reflected well. SOPD does not plan the budget absorption well. The planning is made just for formality and does not reflect the real budget absorption planning so SOPD does not have target guideline when the budget can be absorbed well. The unfinished project will affect the rest of the programs planned by the government. The program will face many obstacles and cannot be realized in the budget year, so the budget provided by PABD cannot be realized.

It is the step of identifying possibilities and to build vision of what is desired. Imaging is a step to make an image about desired future by making vision. Vision itself is a positive idea about the desired future. In this step the effect of each scenario is identified, the description created through vision is not a short term purpose but a long term purpose. 
That vision is appropriate with the condition of the desired budget absorption in East Kotawaringin in the future. To reach the acceleration of budget absorption in East Kotawaringin which is economic, efficient, and effective it needs qualified and dedicated human resources. Human resource is important to develop a region. By applying budget absorption in the beginning of the year, the development will be realized and it will affect people's prosperity and the start of development will give more opportunity for people to get job to decrease the number of unemployment people, the number of poverty, increase the volume of money cycle in East Kotawaringin. In other side, it will also push a better economic growth and increase people's income so it will directly affects poor people's prosperity.

This step is about considering information, identifying choices and decision making about what planning scenario will be applied. According to the scenario and the previous vision and mission, this deciding step is to choose what strategy that is most suitable for the scenario that has been made. Refers to the analyzing step, there are four scenarios planning in the acceleration of regional budget absorption in East Kotawaringin as follows:

- Scenario A (A Mature Budget Planning Supported By Regional Government's Commitment)

- Scenario B (A Premature Budget Planning Supported By Regional Government's Commitment).

- Scenario C (A Mature Budget Planning But Not Supported By Regional Government's Commitment).

- Scenario D (A Premature Budget Planning And Not Supported By Regional Government's Commitment).

\section{CONCLUSION}

A scenario planning is a good planning in forming an acceleration of the regional budget absorption in East Kotawaringin which does not run effectively yet. Based on the crossimpact analysis toward trend tendency, the most drivers' variable is budget planning, while the most dependent variable is regional government's commitment. Furthermore, from driving force analysis what is mostly dominant toward budget absorption, there are four scenarios planning. Based on those four scenarios, scenario B (premature budget planning and supported by regional government's commitment) is the most closely reflection of the condition in East Kotawaringin.

\section{REFERENCES}

1. Domai, T. (2010). Manajemen Keuangan Publik. Malang: Universitas Brawijaya Press.

2. Halim, A. (2014). Manajemen Keuangan Sektor Publik (2nd Ed). Salemba Empat.

3. Lindgren, M., \& Hans, B. (2003). Scenario Planning: The Link Betweeen Future and Strategy. New York: Palgrave Macmillan.

4. Mardiasmo. (2009). Akuntansi Sektor Publik. Yogyakarta: Andi Offsite

5. Noor, I. (2013). Desain Inovasi Pemerintahan Daerah. Universitas Brawijaya Press.

6. Rahajeng, A. (2016). Perencanaan Penganggaran Keuangan Daerah. Yogyakarta: Gahjah Mada University Press.

7. Riyadi., \& Bratakusumah, D. S. (2004). Perencanaan Pembangunan Daerah: Strategi Menggali Potensi dalam Mewujudkan Otonomi Daerah. Jakarta: Gramedia Pustaka Utama.

8. Sjafrizal. (2015). Perencanaan Pembangunan Daerah dalam Era Otonomi. Jakarta: PT. Rajagrafindo Persada.

9. Solihin, D. (2016). Percepatan Penyerapan Anggaran Daerah. (Bahan Presentasi Dialog Rektor dengan DPRD Kabuapten Cianjur di Bandung Tanggal 28 September 2016) Jakarta: Badan Perencanaan Pembangunan Nasional.

10. Pemerintahan Provinsi Kalimanatan Tengah (2014), Sistem Perencanaan dan Pengendalian Percepatan Penyerapan Anggaran (SP4A) Provinsi Kalimanatan Tengah Tahun 2014. Biro Administrasi Pembangunan Setda Provinsi Kalimantan Tengah. 